\title{
Material of Burned Coal Wastes Spoil Heaps As Source of Mullite for Ceramic Industry
}

\author{
Tomáš Daněk $^{1 \mathrm{a}}$, Jan Jelínek $^{1,2} \mathrm{~b}$, and Jan Thomas ${ }^{2,3 \mathrm{c}}$ \\ ${ }^{1}$ Institute of Geological Engineering, Faculty of Mining and Geology, VŠB - Technical University of Ostrava, Czech Republic \\ ${ }^{2}$ Institute of Clean Technologies for Mining and Utilization of Raw Materials for Energy Use, Faculty of Mining and Geology, VŠB - \\ Technical University of Ostrava, Czech Republic \\ ${ }^{3}$ Institute of Environmental Engineering, Faculty of Mining and Geology, VŠB - Technical University of Ostrava, Czech Republic
}

\begin{abstract}
Burning or burnt out mine spoil heaps may be potential sources of materials not only for building purposes, but they may also be used in the ceramic industry. Decay of the coal mass contained in the mine spoil heaps often leads to self-ignition. As a consequence of spontaneous mine fire, which may approach $1600^{\circ} \mathrm{C}$, the surrounding waste rock undergoes thermal conversion. The temperature conditions inside the burning spoil heaps are analogous to the production conditions of refractory opening materials and fillers in rotary furnaces. The article deals with an analysis of anthropogenic porcelanites in terms of their phase composition and their possible application in the ceramic industry. The material under analysis underwent X-ray diffraction, electron microscopy and X-ray fluorescence to identify its chemistry and mineralogy. The article also proposes an enrichment method for the given material, through which a higher proportion of its useful component, mullite, may be obtained. Applying this method, approximately $60 \%$ relatively pure separated raw material suitable for the ceramic industry may be obtained from the original material.
\end{abstract}

\section{Introduction}

The issue of burning mine spoil heaps in coal deposits concerns many coal districts world-wide. Above all, it concerns localities with underground mining as the waste rock contains large amounts of residual coal mass. In connection with oxidation processes, the coal mass may self-ignite. The decay of fossil organic matter is the major energy resource for such processes. Most heat is released when unsaturated organic compounds oxidise into humic-acid-type compounds. Tvrdý and Sejkora [1] described the high-temperature carbonisation process occurring in the reducing medium under the temperatures exceeding $1000{ }^{\circ} \mathrm{C}$. The thermal effect significantly heats the surrounding sedimentary rocks and they get gradually fired in a natural way.

Numerous works have dealt with the issue of self-ignition, monitoring and the processes occurring inside the mine spoil heaps $[2,3]$. Some authors focused on the petrology, mineralogy and geochemistry of mine spoil heaps in their studies $[4,5]$. Others deal with the chemical processes taking place in the mine spoil heaps under different temperatures $[2,6]$. Few works reported the exploitation of the spoil material as the filling material for building purposes. However, studies applying anthropogenic porcelanites in the ceramic industry are rare [7].

\section{Materials}

The studied locality was the mine spoil heap called Ronna situated in the Kladno Coal District in the Czech Republic. When selecting the locality, the principal criterion was the high abundance of coal mass in the waste rock (up to $17 \%$ ) and high proportion of claystone in the accompanying rocks. The spoil material is very heterogeneous. Inside the spoil heap body there are rocks with coal ingredient, low grade coal mass, coal dust from cleaning the cross cuts, tailings from coal washing, cinders, and frequently debris and municipal waste. Attention during sampling was drawn to anthropogenic porcelanites (material macroscopically similar to natural porcelanites). As the mine spoil was undergoing reclamation works at the time of sampling, the samples come from different depths of the mine spoil heap. In this way, the samples represent a mean sample from the given mine spoil heap section.

\section{Methods}

X-ray powder diffraction (XRD) and X-ray fluorescence $(\mathrm{XRF})$ were the major applied analytical methods to determine the chemical and mineralogical composition of the thermally altered material samples.

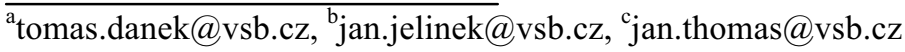

This is an Open Access article distributed under the terms of the Creative Commons Attribution License 4.0, which permits unrestricted use, distribution, and reproduction in any medium, provided the original work is properly cited. 
We used an electron microscope to determine the character of the different grains in the samples.

The samples were crushed for the purposes of the laboratory research of the chemical composition and of the mineral phases. A sieve analysis followed. All the samples were unscreened and $90 \%$ of the grains were below $2 \mathrm{~mm}$. Subsequently, the samples were homogenised and ground to obtain analytical fineness.

According to the analyses of the chemical (tab. 1) and mineral composition (tab. 2) [7], none of the samples complied with the requirements set for industrially made raw materials for the ceramic industry. The mean contents of the observed mineral phases (particularly mullite - tab. 2) did not amount to the desired level of $10-30 \%$. Therefore, it was necessary to propose an enrichment method for the given material in order to enhance the abundance of mullite. The experiment was grounded in enriching the material by means of firing. Identification of the optimal conditions for the mullite crystal formation is one of the basic requirements in the industrial production of fired ceramic bodies of varying alumosilicate composition, including high-strength porcelain. The temperature of $1250{ }^{\circ} \mathrm{C}$ and 3-hour firing were experimentally identified as optimal. The method is described in a greater detail in [7].

Table 1. Mean percentage abundance of basic indicators of the interest material chemical composition.

\begin{tabular}{lccccccccccc}
\hline Sample & $\mathrm{Al}_{2} \mathrm{O}_{3}$ & $\mathrm{SiO}_{2}$ & $\mathrm{MgO}$ & $\mathrm{P}_{2} \mathrm{O}_{5}$ & $\mathrm{SO}_{3}$ & $\begin{array}{c}\mathrm{Cl} \\
{[\%]}\end{array}$ & $\mathrm{K}_{2} \mathrm{O}$ & $\mathrm{CaO}$ & $\mathrm{TiO}_{2}$ & $\mathrm{MnO}^{\mathrm{Fe}_{2} \mathrm{O}_{3}}$ \\
\hline Ronna1 & 22.93 & 47.76 & 1.78 & 0.087 & 1.27 & 0.035 & 1.38 & 1.86 & 0.52 & 0.594 & 18.64 \\
Ronna2 & 27.85 & 60.29 & 0.84 & 0.076 & 1.48 & 0.022 & 1.76 & 1.12 & 0.76 & 0.085 & 4.56 \\
Ronna3 & 26.98 & 49.70 & 1.22 & 0.092 & 1.12 & 0.022 & 1.51 & 1.62 & 0.60 & 0.151 & 9.86 \\
Ronna4 & 27.86 & 61.25 & 0.62 & 0.085 & 0.17 & 0.061 & 1.56 & 1.22 & 0.60 & 0.051 & 3.75 \\
Ronna5 & 26.14 & 61.64 & 0.57 & 0.092 & 1.22 & 0.031 & 1.59 & 1.11 & 0.52 & 0.060 & 3.80 \\
Ronna6 & 26.21 & 61.22 & 0.41 & 0.096 & 1.8 & 0.016 & 1.55 & 0.89 & 0.50 & 0.058 & 3.72 \\
\hline
\end{tabular}

Table 2. Results of X-ray powder diffraction analysis in the original samples (mean percentage) and $1250{ }^{\circ} \mathrm{C}$ firing lasting for 2.5 hours.

\begin{tabular}{cccccccc}
\hline & Amorphous & Mullite & Indialite & $\begin{array}{c}\text { Quartz } \\
{[\%]}\end{array}$ & Hematite & Cristobalite & Others \\
\hline $\begin{array}{c}\text { Before firing } \\
\text { Bulk sample } \\
\text { After firing 1250 }\end{array}$ & 59.2 & 5.2 & - & 18.1 & 4.8 & 1.8 & 13 \\
Ro1 & 38.75 & 35.6 & - & 2.63 & 16.12 & 6.9 & - \\
Ro2 & 42.5 & 40.01 & 0.78 & 4.16 & 3.33 & 9.22 & - \\
Ro3 & 37.7 & 38 & 0.99 & 4.69 & 8.59 & 9.97 & 0.06 \\
Ro4 & 46.1 & 34.9 & - & 5.82 & 3.31 & 8.47 & 1.41 \\
Ro5 & 31.9 & 44.5 & - & 11.23 & 3.74 & 8.63 & - \\
Ro6 & 37.9 & 39.60 & - & 10.14 & 2.94 & 9.42 & - \\
\hline
\end{tabular}

The limit temperature of $1250{ }^{\circ} \mathrm{C}$ was set experimentally with respect to the crystallisation character of mullite and formation of porous material. Macroscopically, all the fired samples had the character of a granulated porous mass (Fig.1a), which contained grains of white, black and red-brown-grey colour. The sample disintegrated into the individual grains already at a low mechanical action. X-ray powder diffraction helped to identify the different mineral phases in the samples. Next, the research focused on the determination of the mineral composition of the grain groups. A mixed sample was made as the mineral distribution was analogous in all the samples. From this mixed sample, grains were chosen for the different classes according to colour: type A black (37.11 wt \%), type $\mathrm{B}$ white $(53.73 \mathrm{wt} \%)$ and type $\mathrm{C}$ red-brown $(9.16$ wt \%). A part of each class was used to determine the abundances of the mineral phases by means of XRD and the remaining parts were used to prepare a polished section to study its character and chemical composition using a scanning electron microscope (SEM) with an energy dispersion spectrometer (EDS).

\section{Results and discussion}

Based on the analysis of the chemical composition, the interest content of $\mathrm{A} 12 \mathrm{O} 3$ in the observed samples ranged from 22.93 to $27.86 \%$ (tab. 1), which complies to the criteria set for the raw materials to produce quartz fireclay $(10-30 \%)$ [8]. The enriched material also meets the criteria for the content of glass phase (30 $60 \%$ ) - see tab. 2.

The results of the whole sample X-ray powder diffraction imply that the enrichment process increased 
mullite as high as $44.5 \%$ (sample Ronna 5). Very satisfactory values were also acquired in other samples, ranging from 34.9 to $40.0 \%$ (tab. 2). Glass phase in the
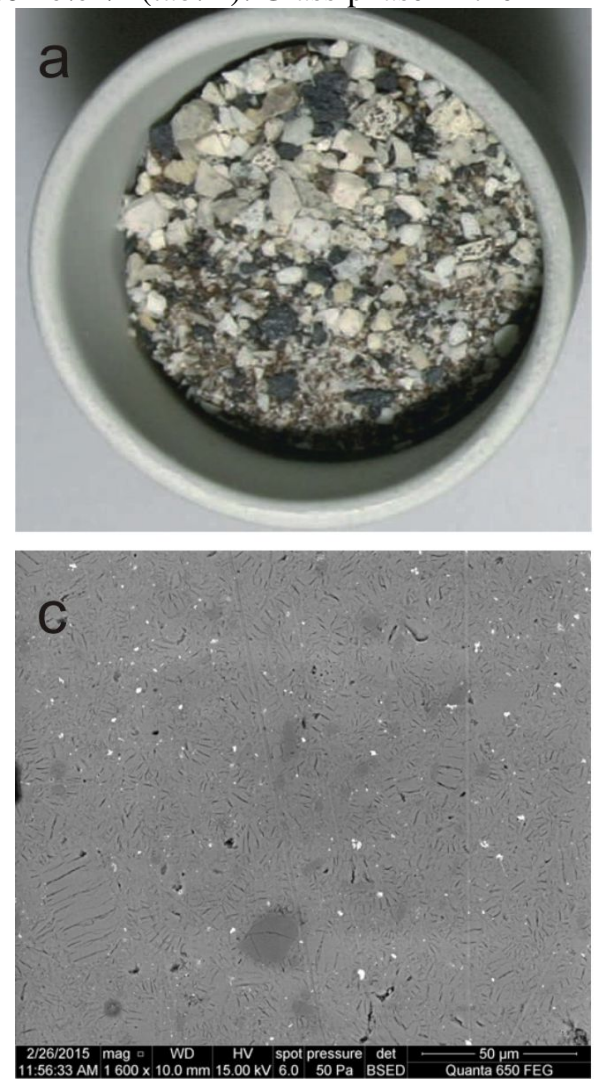

region from 31.9 to $46.1 \%$ was identified in all the samples (tab. 2).
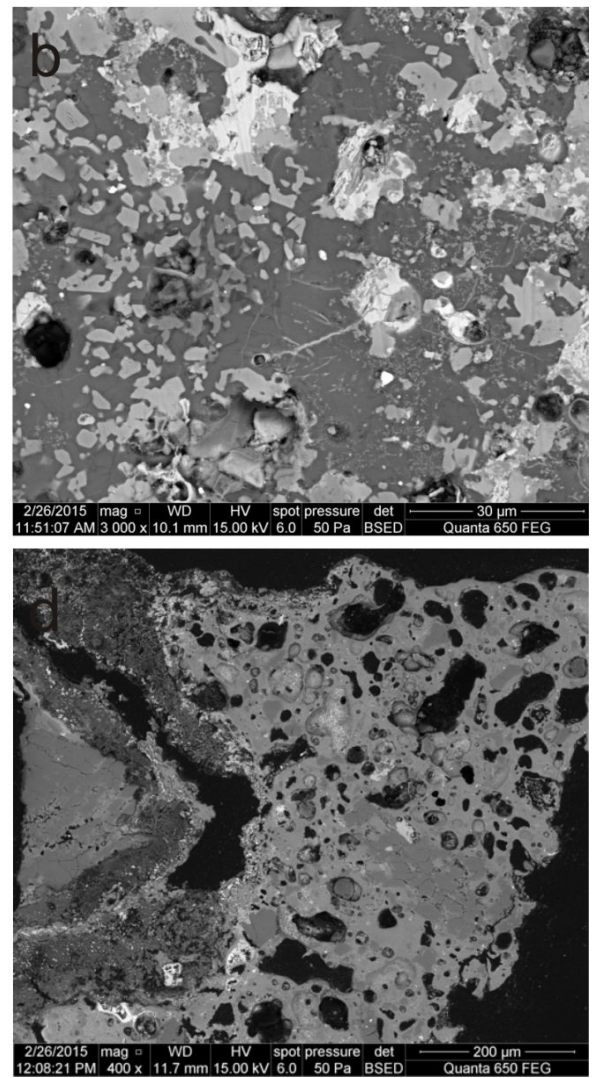

Figure1. Sample Ronna 1 after firing at $1250^{\circ} \mathrm{C}$. Photograph of specimen a), SEM microphotographs of grains: b) type A-black, c) type B-white and d) type C-red-brown (all with BSED)

The SEM and XRD analysis results of the different types of grains show that the type A grains are highly porous and contain high proportions of glassy material (Fig. 1b). From the chemical point of view, it is predominantly made up by iron oxides and hydroxides in various mineral forms (hematite, magnetite, goethite).

The type B grains predominantly consist of glassy material and the remains are made up by mullite and quartz (Fig. 1c). The glassy material is interwoven with an abundant network of rosette-like micro fissures, but is otherwise compact. The type $\mathrm{C}$ grains (Fig. 1d) are porous and most diverse as for their mineralogy and chemistry. They have the lowest proportion of the glassy material and, on the other hand, the highest percentages of mullite and quartz. Hematite, calcite and cordierite (indialite) also scantly occurred.

It may be stated that the material as a whole represents a quality raw material for refractory ceramics. Its useful value may be even increased selecting a suitable separation method of the dark grains of type A which are sources of iron oxides and amount to $37 \%$ in the material.

\section{Conclusion}

The study offers an option how to utilise thermally modified spoil heap material in the ceramic industry. The implemented experiments proposed and tested the thermal enrichment method for the given material. Via the proposed method and subsequent suitable separation of black grains, anthropogenic porcelanites may render high quality materials with high mullite content for the ceramic industry.

\section{Acknowledgements}

This publication has been created within the project Support of VŠB-TUO activities with China with financial support from the Moravian-Silesian Region.This research has been carried out within the project Institute of clean technologies for mining and utilization of raw materials for energy use, reg. no. CZ.1.05/2.1.00/03.0082 (ED2.1.00/03.0082) supported by Research and Development for Innovations Operational Program financed by Structural Funds of European Union and from the means of state budget of the Czech Republic. 


\section{References}

1. J. Tvrdý, J. Sejkora, Novotvořené minerální fáze na hořícím odvalu dolu Kateřina v Radvanicích, Uhlí, rudy, geologický průzkum, 7, 3 (2000) 19-24.

2. S.E.T. Bullock, F.G. Bell, Some problems associated with past mining at a mine in the Witbank coalfield, South Africa, Environmental Geology, 33, 1, (1997) 61-71.

3. D. Nichol, N.P. Tovey, Remediation and monitoring of a burning coal refuse bank affecting the Southsea Looproad at Brymbo, North Wales, Engineering Geology, 50 (1998) 309-318.

4. S.A. Novikova, Fayalite from Fe-rich Paralavas of Ancient Coal Fires in the Kuzbass, Russia,Geology of Ore Deposits, 51, 8 (2009) 800-811.
5. E.V. Sokol, E.N. Nigmatulina, N.I. Volkova, Fluorine mineralisation from burning coal spoil-heaps in the Russian Urals, Mineralogy and Petrology, 75 (2002) 23-40.

6. Y. Zheng, P.A. Jensen, A.D. Jensen, A kinetic study of gaseous potassium capture by coal minerals in a high temperature fixed-bed reactor, Fuel, 87 (2008) 3304-3312.

7. J. Jelínek, J. Mališ, T. Daněk, J. Thomas, V. Slivka, Old coal refuse heaps - possible sources of opening materials for the ceramic industry, Inzyniera Mineralna, 12, 1(27) (2011) 61-72

8. M. Gregerová, B. Fojt, V. Vávra, Mikroskopie horninotvorných a technických minerálů, MZM, Brno, 2002. 